\title{
Formulation and Evaluation of Sunscreen Cream from Moringa oleifera and Turbinaria conoides
}

\author{
Rini Yanuarti ${ }^{1}$, Nurfitriyana Nurfitriyana ${ }^{1}$, Muhammad Zuchryanto ${ }^{2}$, Ginanjar Pratama ${ }^{3}$, Aris Munandar $^{3}$, Aidil Fadli \\ Ilhamdy $^{4}$, Jumsurizal Jumsurizal ${ }^{4 *}$, Itok Dwi Kurniawan ${ }^{5}$ \\ ${ }^{1}$ Pharmacy Department, Science and Technology Faculty, Al-Kamal Science and Technology Institute, 11520 Jakarta, Indonesia \\ ${ }^{2}$ Information System Department, Science and Technology Faculty, Al-Kamal Science and Technology Institute, 11520 Jakarta, \\ Indonesia \\ ${ }^{3}$ Fisheries Department, Faculty of Agriculture, Sultan Ageng Tirtayasa University, 42118 Serang, Indonesia \\ ${ }^{4}$ Fisheries Product Department, Marine Science and Fisheries Faculty, Raja Ali Haji Maritime University, 29111 Tanjungpinang, \\ Indonesia \\ ${ }^{5}$ Department of Law, Faculty of Law, Sebelas Maret University, 57126 Surakarta, Indonesia
}

\begin{abstract}
Research on the combination of natural ingredients from brown seaweed and Moringa, to be used as sunscreen has been nothing. Therefore, the objective of this study was to determine the best formulation from sunscreen evaluation. In this study, the ratio of Moringa oleifera and Turbinaria conoides was 1:1 (cream L), 2:1 (cream M), 1:2 (cream N), and control (no added both of natural ingredients) (cream K). The evaluation of sunscreen cream by Sun Protection Factor (SPF) activity, viscosity, $\mathrm{pH}$, homogeneity, and microbial test. SPF values in this study from cream $\mathrm{K}, \mathrm{L}, \mathrm{M}$, and $\mathrm{N}$ were $0.75 \pm 2.31,17.80 \pm 0.97,9.48 \pm 1.41$, and $15.97 \pm 2.38$, respectively. Viscosity values were $22,400 \mathrm{cPs}$ for cream K; 32,400 cPs for cream L; 26,000 cPs for cream M; and 32,800 cPs for cream N. The pH value of sunscreen cream in cream K, L, M, N were 7.30 $\pm 0.02,6.51 \pm 0.02,6.38 \pm 0.04$, and 6.43 \pm 0.04 , respectively. In all of the treatments of sunscreen cream, microbial tests are absent and have good homogeneity. The ratio of 1:1 (cream L) between M. oleifera and T. conoides has a good synergistic effect to ward off UV B light, therefore cream $\mathrm{L}$ is the best sunscreen cream in this study.
\end{abstract}

\footnotetext{
* Corresponding author: jumsurizal2@gmail.com
} 


\section{Introduction}

The development of the cosmetic industry in Indonesia is increasing rapidly. It was indicated by the number of new products circulating in the market, especially through e-marketing [1]. Cosmetics that are popular today are products that come from natural ingredients because most women in Indonesia already have a green consumer mindset [2]. Therefore, many natural ingredients are often used as cosmetic products, including natural ingredients that have bioactive components that are good for health [3].

Some requirements of natural products must be easily available, no side effects, no special equipment needed for preparation, renewable resources, and they are inexpensive [4]. As an archipelagic country, Indonesia has many types of seaweed [5]. One of the seaweeds that have the potential to be used as cosmetics is brown seaweed. Brown seaweed has bioactive components that are good for human health but are rarely used optimally. The types of bioactive compounds phenol hydroquinone, flavonoids, triterpenoids, steroids, and saponins are found in the extract of Turbinaria conoides (brown seaweed)[6]. In addition to seaweed, the potential for natural ingredients to be used as cosmetics is the Moringa [7]. It was known to have various benefits for human health and is called the miracle tree [8] . Moringa leaf extract (M. oleifera) was known to have bioactive components such as alkaloids, anthraquinones, flavonoids, glycosides, saponins, steroids, terpenoids, and tannins $[7,9,10]$.

The tropical climate in Indonesia makes sun exposure very high, especially in the summer [5]. Human skin naturally has the ability to protect the skin from exposure to UV light (ultraviolet), but this protection has not been effective against UV light, especially UV-B. Generally, to protect exposure, humans use sunscreen cream to reduce it [11].

Various kinds of natural ingredients are now being developed to be used as sunscreen creams [5]. However, there is still no combination between brown seaweed (T. conoides) and Moringa. The objective of this study was to determine the best sunscreen cream formulation from the combination of Moringa and $T$. conoides.

\section{Materials and method}

\subsection{Materials}

The Moringa were collected from Kareo District, Serang and the brown seaweed $T$. conoides were collected from Cimandiri beach, Lebak on July-August 2021. Both area were in Banten Province, Indonesia.

\subsection{Moringa preparation}

Moringa leaves are washed with demineralized water, then dried by drying in the sun for 3 days. The dried
Moringa leaves are then mashed using a mortar, so as to produce Moringa leaf powder [12].

\subsection{T. conoides preparation}

T. conoides was washed using demineralized water, then soaked in demineralized water for 24 hours. The soaked seaweed was then mashed with a blender, then demineralized water added in a ratio of $1: 1$, to produce a homogeneous $T$. conoides porridge [13].

\subsection{Formulation of sunscreen cream}

The oil phase (emulgide (Merck),stearic acid (Merck), cetyl alcohol (Merck), and liquid paraffin (Merck)) and water phase (glycerine (Merck), TEA (Merck), and aquades) materials are heated at a temperature of 70$75^{\circ} \mathrm{C}$ respectively until they melt. After the cream base was formed, then the additive was added ( $T$. conoides porridge, moringa leaf powder, and methylparaben). Each of the materials was mixed when every phase have reached a temperature of $\pm 40^{\circ} \mathrm{C}$. They mixed and stirred slowly until the formulation was homogeneous[13].

Table 1. Formulation sunscreen cream [5]

\begin{tabular}{|c|c|c|c|c|}
\hline \multirow[t]{2}{*}{ Materials } & $\begin{array}{c}\text { Cream } \\
\mathrm{K}\end{array}$ & $\begin{array}{c}\text { Cream } \\
\text { L }\end{array}$ & $\begin{array}{c}\text { Cream } \\
\mathrm{M}\end{array}$ & $\begin{array}{c}\text { Cream } \\
\mathrm{N}\end{array}$ \\
\hline & \multicolumn{4}{|c|}{$(\%)$} \\
\hline \multicolumn{5}{|l|}{ Oil phase } \\
\hline Cetyl alcohol & 2 & 2 & 2 & 2 \\
\hline Emulgide $^{(B)}$ & 8 & 8 & 8 & 8 \\
\hline Liquid paraffin & 2 & 2 & 2 & 2 \\
\hline Stearic acid & 4 & 4 & 4 & 4 \\
\hline \multicolumn{5}{|l|}{ Water phase } \\
\hline Aquades & ad.100 & ad. 100 & ad.100 & ad. 100 \\
\hline Glycerin & 2 & 2 & 2 & 2 \\
\hline $\begin{array}{l}\text { Triethanolamine } \\
\text { (TEA) }\end{array}$ & 1 & 1 & 1 & 1 \\
\hline \multicolumn{5}{|l|}{ Additive } \\
\hline Methyl paraben & 0.2 & 0.2 & 0.2 & 0.2 \\
\hline Moringa powder & 0 & 15 & 20 & 10 \\
\hline $\begin{array}{l}\text { Seaweed } \\
\text { porridge } \\
\text { conoides })\end{array}$ & 0 & 15 & 10 & 20 \\
\hline
\end{tabular}

ad.100 : additional to 100

\subsection{Sun Protection Factor (SPF) activity}

Determination of the effectivene ss of sunscreen using a UV-Vis spectrophotometer (Hitachi V-3900 H). A sample of $400 \mathrm{mg}$ was dissolved in $25 \mathrm{~mL}$ of methanol (Merck) until homogeneous. The test absorption curve is used with a wavelength of $290-320 \mathrm{~nm}$, then determines the average absorption (Ar) with an interval of $10 \mathrm{~nm}$ with three replicates [14]. The data is processed using the Mansur equation [15].

$$
\mathrm{SPF}=\mathrm{CF} \times \sum_{290}^{320} \mathrm{EE}(\chi) \times \mathrm{I}(\chi) \mathrm{x} \text { abs }(\chi)
$$

Information:

$\mathrm{CF}=$ correction factor

$\mathrm{EE}=$ spectrum of erytermal effects 
I = spectrum of intensity from the sun abs $=$ absorbance of the sample

\subsection{Evaluation physics of sunscreen cream}

Physical evaluation parameters include $\mathrm{pH}$, viscosity, and homogeneity. The $\mathrm{pH}$ meter (CP-401 Elmiron) is used to determine a $\mathrm{pH}$ value [5]. Viscosity measurement using a viscometer (Brookfield DV-E) with spindle no 5 . Homogeneity by judging based on appearance and touch affinity [16].

\subsection{Total microbial count}

The total microbial test refers to the Indian Pharmacopoeia 2010. Microbial tests was carried out on all treatments including control (cream K)[16] .

\section{Results and discussion}

\subsection{SPF activity of the sunscreen cream}

Based on the results of SPF activity in Table 2, cream L (ratio $M$. oleifera and $T$. conoides was $1: 1$ ) has the highest SPF value (17.80) when compared to other treatments. It was due to the synergistic effect between Moringa leaf powder and T. conoides porridge [17]. Both contain has phenolic and flavonoids, which are photoprotective and UV absorb [18]. However, the SPF Cream L value was lower than nanoemulsion from moringa extract with an SPF value of 33.3 [19], and higher when compared to $T$. conoides methanol extract (16.7)[6].

In cream $\mathrm{M}$ with a ratio of $M$. oleifera and $T$. conoides 2:1, the SPF value (9.48) was lower than the other two treatments (Cream L \& Cream N). It was due to used the powder Moringa leaf in formulations so that the UV photoprotective components are not extracted properly $[7,10,12]$.

Table 2. Evaluation of sunscreen cream

\begin{tabular}{|l|c|c|c|c|}
\hline Sample & $\begin{array}{c}\text { Cream } \\
\text { K }\end{array}$ & $\begin{array}{c}\text { Cream } \\
\text { L }\end{array}$ & $\begin{array}{c}\text { Cream } \\
\text { M }\end{array}$ & $\begin{array}{c}\text { Cream } \\
\text { N }\end{array}$ \\
\hline SPF & 0.75 & 17.80 & 9.48 & 15.97 \\
\hline pH & 7.30 & 6.51 & 6.38 & 6.43 \\
\hline $\begin{array}{l}\text { Viscosity } \\
\text { (cPs) }\end{array}$ & 22,400 & 32,400 & 26,000 & 32,800 \\
\hline Homogeneity & good & good & good & good \\
\hline Microbial test & nil & nil & nil & nil \\
\hline
\end{tabular}

\subsection{Evaluation physics of the sunscreen cream}

The results of $\mathrm{pH}$ consisted in all cream of the range were 6.38 to 7.50 (Table 2). These results indicate that all creams (including control cream) are still within safe limits (6-9) for the use of sunscreen cream on the skin $[9,21]$. Based on the viscosity results obtained the cream K, L, M, N values were 22,400; 32,400; 26,000; $32,800 \mathrm{cPs}$, respectively. The high viscosity value of the cream was directly proportional to the concentration of $T$. conoides given [22]. Brown seaweed contains alginate which can increase the viscosity value. Alginate is a hydrocolloid component that functions as a gelling agent which is only found in brown seaweed [23]. All treatments had good homogeneity with marked affinity and good appearance, although there were moringa powders which looked disorganized but in actual cream they were well dispersed (Fig. 1).

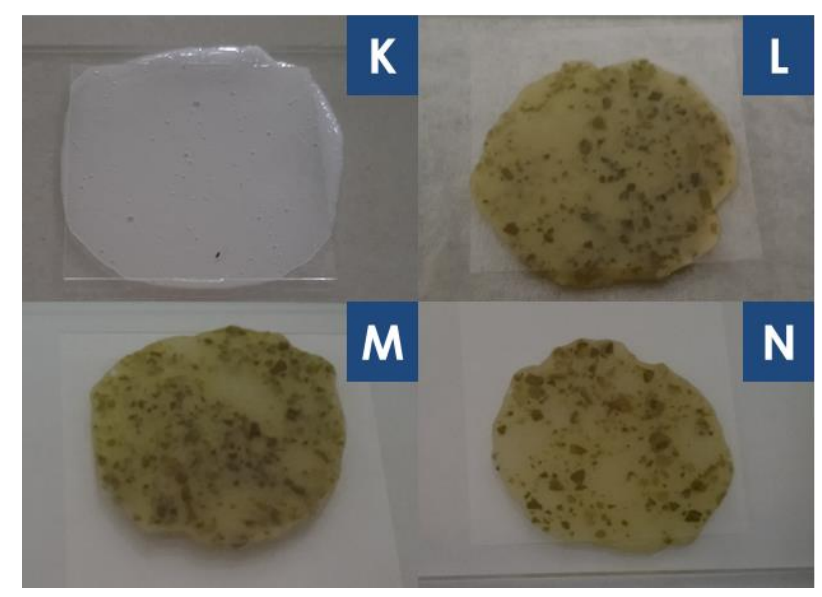

Fig. 1. Sunscreen cream.

\subsection{Microbial test of the sunscreen cream}

Based on the results of microbial tests in all treatments (including control) the microbial are absent. It was due to the presence of methyl paraben used. Methyl paraben is an additive used as a preservative [5]. This material has the ability to protect the cream from the growth of bacteria and fungi [16] .

\section{Acknowledgement}

Special thanks to the Ministry of Education, Culture, Research, and Technology for the related grant with scheme PDP.

\section{References}

1. Lusiah, Hendra, W. Suryani, and E. Margery, Int. J. Chem. Eng. Syst. 5 (2020)

2. N. Amberg and C. Fogarassy, Resources 8, 3 (2019)

3. A. Aswal, M. Kalra, and A. Rout, Der Pharm. Lett. 5, 1 (2013)

4 R. Jangde and S. J. Daharwal, Res. J. Top. Cosmet. Sci. 2, 2 (2011)

5 G. Pratama, R. Yanuarti, A. F. Ilhamdy, and M. P. Suhana. Formulation of sunscreen cream from Eucheuma cottonii and Kaempferia galanga (zingiberaceae), in Proceedings of The 3rd Embrio International Workshop, EIW, 9-10 October 2018, Bogor, Indonesia (2019)

6. R. Yanuarti, N. Nurjanah, E. Anwar, and G. Pratama, Biosfera 34, 2 (2017)

7. D. Meireles, J. Gomes, L. Lopes, M. Hinzmann, and J. Machado, Adv. Tradit. Med. 20, 4 (2020)

8. A. F. A. Razis, M. D. Ibrahim, and S. B. Kntayya, Asian Pacific J. Cancer Prev. 15, 20 (2014) 
9. A. Ali, N. Akhtar, A. M. Mumtaz, M. S. Khan, F. M. Iqbal, and S. S. Zaidi, African J. Pharm. Pharmacol. 7, 6 (2013)

10. M. Velázquez-Zavala, I. E. Peón-Escalante, R. Zepeda-Bautista, and M. A. Jiménez-Arellanes, Rev. Chapingo, Ser. Hortic. 22, 2 (2016)

11. A. K. Mishra, A. Mishra, and P. Chattopadhyay, Trop. J. Pharm. Res. 10, 3 (2011)

12. Y. Singh and K. Prasad, Int. J. Agric. Food Sci. Technol. 4, 4 (2013)

13. R. Yanuarti, Nurjanah, E. Anwar, and G. Pratama, FishtecH 10, 1 (2021)

14. M. Pissavini, L. Ferrero, V. Alard, U. Heinrich, and H. Tronnier, Cosmet. Toilet. 118, 10 (2003)

15. J. D. S. Mansur, M. N. R. Breder, M. C. D. A. Mansur, and R. D. Azulay, An. Bras. Dermatol. 61 (1986)

16. A. P. Mishra, S. Saklani, L. Milella, and P. Tiwari, Asian Pac. J. Trop. Biomed. 4 (2014)

17. T. Amnuaikit and P. Boonme, J. Appl. Pharm. Sci. 3, 8 (2013)

18. M. Radice, S. Manfredini, P. Ziosi, V. Disette, P. Buso, A. Fallacara, S. Vertuani, Fitoterapia 114 (2016)

19. A. W. Indrayani, I. G. A. Artini, I. A. A. Widhiarthini, N. W. Tianing, and I. M. Jawi, Bali Med. J. 9, 3 (2020)

20. G. Varsha, B. Pooja, and S. Pournima, Int. J. Adv. Community Med. 1, 3 (2018)

21. F. P. Gasparro, M. Mitchnick, and J. F. Nash, Photochem. Photobiol. 68, 3 (1998)

22. W. A. J. P. Wijesinghe and Y.-J. Jeon, Phytochem. Rev. 10, 3 (2011)

23. A. Rasheed, S. N. Shama, S. Mohanalakshmi, and V. Ravichandran, Orient. Pharm. Exp. Med. 12, 4 (2012) 